\title{
IDENTIFIKASI KESULITAN REPRESENTASI MATEMATIS SISWA SMP PADA PEMECAHAN MASALAH PECAHAN
}

\author{
Syarifuddin \\ Program Studi Pendidikan Matematika, STKIP Bima \\ "Email korespondensi: syarifuddin_mat@stkipbima.ac.id
}

\begin{abstract}
ABSTRAK
Penelitian ini bertujuan untuk mengidentifikasi kesulitan representasi siswa pada pemecahan masalah pecahan. Metode penelitian yang digunakan adalah deskriptif eksploratif. Subyek yang digunakan dalam penelitian ini adalah Penelitian ini merupakan penelitian deskriptif eksploratif yang dilakukan pada siswa salah satu SMP Negeri di Kabupaten Bima NTB dengan menggunakan partisipan sebanyak 10 orang.. Siswa diberikan tes berupa soal untuk mengidentifikasi kesulitan representasi siswa dan untuk mengetahui bentuk representasi yang dihasilkan oleh siswa. Hasil penelitian menunjukan: 1) masih ada siswa yang kesulitan dalam merepresentasikan verbal, gambar, dan simbol aritmatika tentang terbentuknya pecahan; 2) masih ada siswa yang penyelesaian masalah pecahan dengan mengguanakan representasi verbal tetapi tidak bisa merepresentasikan dengan simbol aritmatika dan gambar; 3) siswa masih kesulitan menyelesaikan masalah bentuk pecahan ke bentuk pecahan sederhana.
\end{abstract}

Kata kunci: representasi, pemecahan masalah, pecahan

\begin{abstract}
Purpose of the research is to identify difficulties of the students' representative for solving the fraction problems. The method used is descriptive explorative. The study is done to students of a state Junior High School in Bima, West Nusa Tenggara, using 10 participants. They are given a test including some problems to identify difficulties of students' representation and to observe the kinds of representation made by the students. The results are: 1) there are students who are difficult to represent arithmetic' verbal, picture and symbols in forming fraction; 2) there are students who are solving fraction problem using verbal representation unless cannot represent in arithmetic's symbols and drawings; 3 ) the students are difficult to solve the fraction problem into simple fraction forms.
\end{abstract}

Keywords: representation, problem solving, fraction

\section{PENDAHULUAN}

Perolehan keterampilan kognitif yang kompleks seperti membaca, menulis dan menghitung tergantung pada "sistem membangun hambatan", (Spelke, 2000). Sejak lahir otak manusia dilengkapi dengan sistem pengetahuan inti domain-spesifik, yang memungkinkan 
untuk representasi awal dan penalaran tentang jenis-jenis peristiwa tertentu dan entitas seperti benda, orang, tempat dan numerosities (numeris) (Spelke, 2000). Kemampuan representasi tersebut akan terus berkembang sesuai dengan perkembangan umur maupun perkembangan tingkat pemikiran.

Representasi adalah model atau bentuk pengganti dari suatu situasi masalah yang digunakan untuk menemukan solusi. Sebagai contoh, suatu masalah dapat direpresentasikan dengan obyek, gambar, kata-kata, atau simbol matematika (Jones \& Knuth, 1991). Dalam NCTM (2000), dinyatakan bahwa representasi merupakan cara yang digunakan seseorang untuk mengkomunikasikan jawaban atau gagasan matematik yang bersangkutan.

Lesh, Post dan Behr (dalam Hwang, Chen, Dung, \& Yang, 2007) membagi representasi yang digunakan dalam pendidikan matematika dalam lima jenis, yaitu representasi objek dunia nyata, representasi konkret, representasi simbol aritmatika, representasi bahasa lisan atau verbal dan representasi gambar atau grafik. Memunculkan kelima jenis representasi tersebut, akan berbeda-beda cara yang dilakukan oleh siswa. NCTM (2000) menetapkan standar representasi yang diharapkan dapat dikuasai siswa selama pembelajaran di sekolah yaitu: 1) Membuat dan menggunakan representasi untuk mengenal, mencatat atau merekam, dan mengkomunikasikan ide-ide matematika; 2) Memilih, menerapkan, dan melakukan translasi antar representasi matematis untuk memecahkan masalah; 3) Menggunakan representasi untuk memodelkan dan menginterpretasikan fenomena fisik, sosial, dan fenomena matematika.

Penggunaan representasi sebagai sarana mengomunikasikan ide-ide matematika abstrak adalah fokus dari penelitian dalam pengetahuan guru dan siswa (Borko \& Putnam, 1996). Dalam NCTM (2000) dijelaskan bahwa standar proses pembelajaran matematika meliputi 1) pemecahan masalah, 2) penalaran dan bukti, 3) komunikasi, 4) koneksi, dan representasi.

Representasi sangat berperan dalam upaya mengembangkan dan mengoptimalkan kemampuan matematika siswa. Menurut Jones (2000) beberapa alasan penting yang mendasarinya adalah sebagai berikut: 1) Kelancaran dalam melakukan translasi di antara berbagai bentuk representasi yang berbeda, merupakan kemampuan dasar yang perlu dimiliki siswa untuk membangun konsep dan berpikir matematis; 2) Cara guru dalam meyajikan ideide matematika melalui berbagai representasi akan memberikan pengaruh yang sangat besar 
terhadap pemahaman siswa dalam mempelajari matematika; 3) Siswa membutuhkan latihan dalam membangun representasinya sendiri sehingga memiliki kemampuan dan pemahaman konsep yang kuat dan fleksibel yang dapat digunakan dalam memecahkan masalah.

NCTM (2000) menyarankan bahwa siswa diperlukan untuk memahami dan meningkatkan konsep-konsep matematika dan operasi. Dengan kata lain, menggunakan representasi yang berbeda dari informasi di dalam kelas memperkuat metode pembelajaran dan meningkatkan keberhasilan mereka dengan rujukan terhadap berbagai sumber informasi.

Representasi sangat berguna dalam membantu siswa menyelesaikan sebuah masalah dengan lebih mudah, (Sabirin, 2014). Melihat pendapat tersebut, ketika siswa tidak mampu melakukan representasi, maka kecenderungan siswa tersebut tidak mampu menyelesaikan masalah. Hal ini disebabkan oleh beberapa masalah, diantaranya: 1) Kebanyakan siswa kesulitan dalam menyelesaikan masalah pecahan; 2) siswa kesulitan dalam merepresentasikan pengatahuan matematika yang mereka miliki untuk menyelesaikan masalah pecahan.

Berikut representasi pecahan dengan menggunakan pendekatan kuantitatif (Hackenberg \& Lee, 2015).

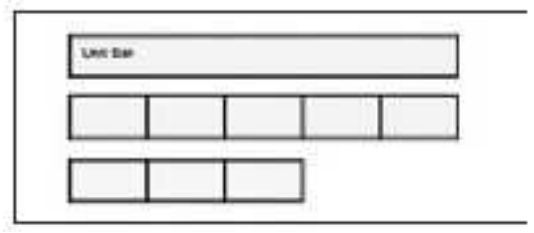

Gambar 1. Representasi $\frac{3}{y}$ dengan pendekatan kuantitatif

Gambar 1 tersebut merupakan ilustrasi dari pecahan $\frac{3}{y}$ dari hasil partisi persegi panjang menjadi lima bagian yang sama dan di iterasi tiga kali.
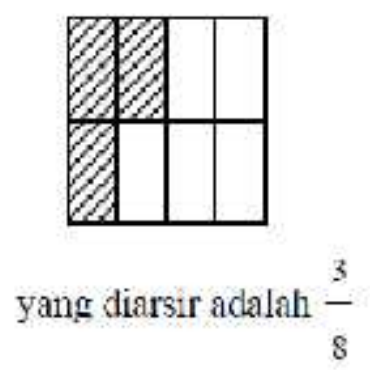

Gambar 2. Representasi pecahan dalam bentuk gambar segi empat

Pendekatan kuantitatif pada gambar 1, dapat di manfaatkan dalam menyelesaikan masalah dalam menentukan bentuk pecahan dengan menggunakan representasi gambar segi empat. 
Pemecahan masalah berperan penting dalam pembelajaran matematika, hal ini dijelaskan dalam NCTM (2000) bahwa pemecahan masalah memainkan peran penting dalam kurikulum karena beberapa alasan: 1) dapat membangun pengetahuan matematika baru; 2) dapat memecahkan masalah yang timbul dalam matematika dan dalam konteks lain; 3) dapat menerapkan dan mengadaptasi berbagai strategi pemecahan masalah; dan 4) memantau dan merefleksikan proses pemecahan masalah matematika. Sedangkan menurut Lester \& Kehle (2003) menyatakan bahwa pemecahan masalah matematis adalah sebagai kegiatan yang mencakup keterlibatan siswa dalam berbagai tindakan kognitif, termasuk mengakses dan menggunakan pengetahuan dan pengalaman sebelumnya.

Pemecahan masalah adalah termasuk situasi dimana seorang individu dalam menghadapi masalah dia tidak dapat menyelesaikannya dengan prosedur rutin (Carlson \& Bloom, 2005). Selanjutnya menurut Schoenfeld (1983) masalah yang terduga dan dapat diselesaikan dengan prosedur rutin atau akrab tidak bisa disebut sebagai masalah melainkan hanya bisa disebut sebagai latihan. Menurut Sriraman (2003) bahwa situasi masalah mencakup 1) tugas yang konseptual, 2) pada hakikatnya subjek mampu memahami dengan pembelajaran sebelumnya oleh organisasi tugas atau orisinalitas, 3) tidak dapat dikerjakan dengan prosedur yang familiar atau akrab, 4) siswa mengalami kebingungan dalam situasi masalah, tapi tidak mengalami kebingungan yang sangat atau artinya masih bisa dijangkau untuk dikerjakan. Dengan demikian dapat disimpulkan bahwa suatu soal dapat dikatakan sebagai masalah matematika jika soal tersebut dapat dijangkau untuk diselesaikan oleh siswa akan tetapi tidak dapat diselesaikan dengan prosedur rutin.

Dari uraian masalah dan teori diatas, maka dilakukan kajian tentang bagaimana siswa merepresentasikan pemecahan masalah matematika. Dengan tujuan untuk mengidentifikasi kesulitan siswa dalam merepresentasikan pemecahan masalah matematika, dan kemudian akan diupayakan menemukan solusi-solusi yang bisa mengatasi masalah-masalah yang ditimbulkan.

\section{METODE PENELITIAN}

Penelitian ini merupakan penelitian deskriptif eksploratif yang dilakukan pada siswa salah satu SMP Negeri di Kabupaten Bima NTB dengan menggunakan partsipan sebanyak 10 orang. Proses penelitian yaitu dengan memberikan tes berupa soal dalam bentuk gambar semi 
konkret untuk mengidentifikasi kesulitan siswa dalam merepresentasikan pemecahan masalah pecahan. Adapun instrumen nya sebagai berikut:

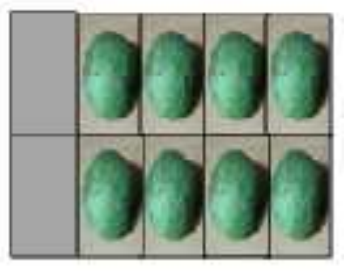

(a)

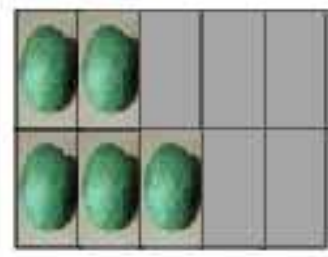

(b)

Gambar 3. Instrumen semi konkrit pecahan

Dari gambar tersebut kemudian di berikan perintah atau pertanyaan:

1. Gamabrakan kotak dan arsir kotak sesuai dengan mangga! Bagaimana bentuk pecahannya?

2. Bagaimana terbentuknya pecahan dari gambar di atas?

Hasil tes tersebut akan dianalisis secara kualitatif untuk mengidentifikasi kesulitan siswa dalam merepresentasi dan untuk mengidentifikasi kesulitan anak yang mengasilkan representasi yang berbeda. Sebelum dianalisis, hasil 10 orang anak tersebut akan di seleksi dan dipisahkan berdasarkan bentuk representasi yang dihasilkan.

\section{HASIL PENELITIAN}

Adapun hasil yang diperoleh dalam penelitian ini adalah sebagai berikut:

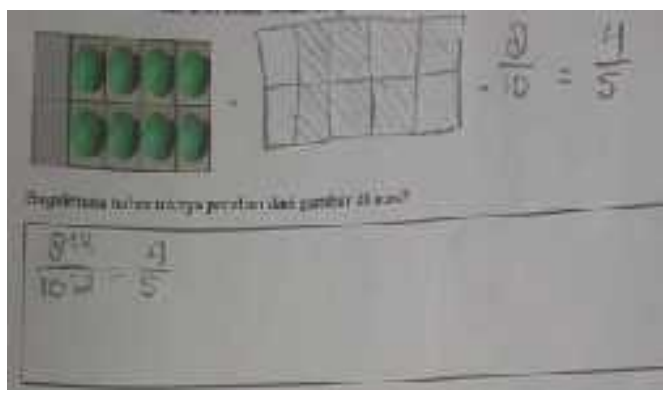

a

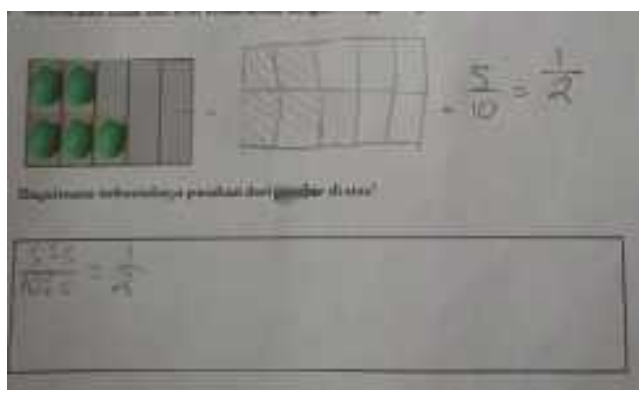

$\mathrm{b}$

Gambar 4. Hasil Pekerjaan S2

Gamabar 4 di atas merupakan hasil pekerjaan Subyek 2. Dari hasil tersebut menunjukan representasi yang dihasilkan oleh S2 merupakan representasi gambar dan representasi simbol aritmatika. Anak tersebut bisa merepresentasikan gambar karena melihat benda konkrit dengan bentuk yang bisa diikuti. Representasi dari gambar tersebut kemudian direpresentasikan dalam bentuk simbol aritmatika dalam bentuk $\frac{\mathscr{y}}{10}$ dengan melihat banyak nya 
benda konkrit. Kemudian menyederhanakan nya dengan melakukan perbandingan. S2 cenderung menjelaskan terbentuknya pecahan tersebut dengan mengguanakan simbol aritmatika.

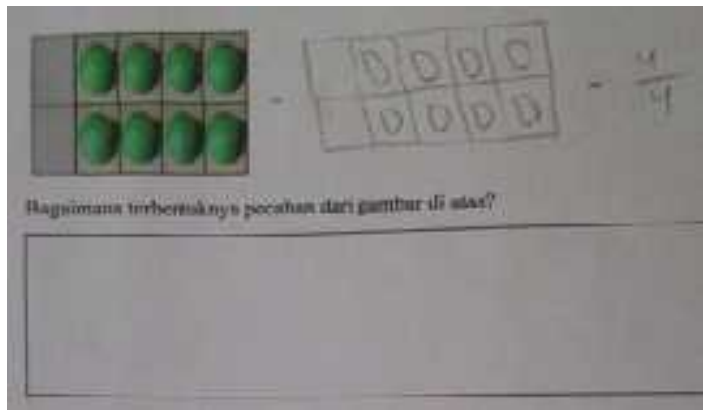

a

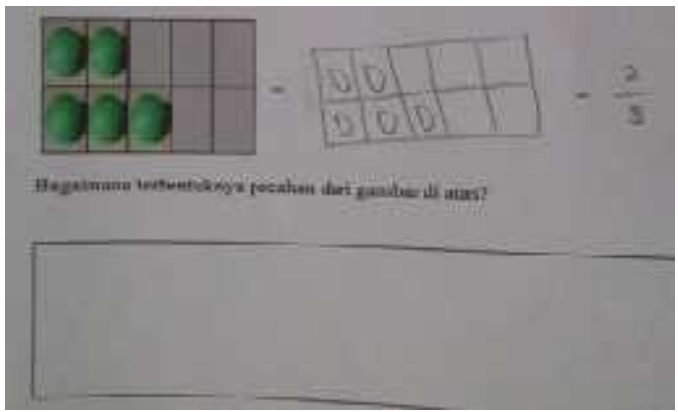

b

Gambar 5. Hasil Pekerjaan S4

Gambar 5 merupakan hasil pekerjaan Subyek 4, yang menunjukan bahwa S4 belum mampu merepresentasikan bentuk gambar konkrit ke dalam bentuk arsiran. Siswa tersebut hanya menggambar ulang yang dilihatnya. Kemudian siswa tersebut belum mampu merepresentasikan gambar tersebut kedalam simbol aritmatika baik.

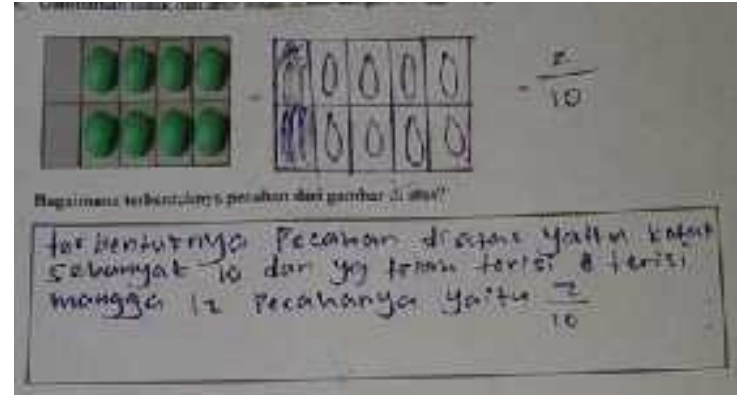

a

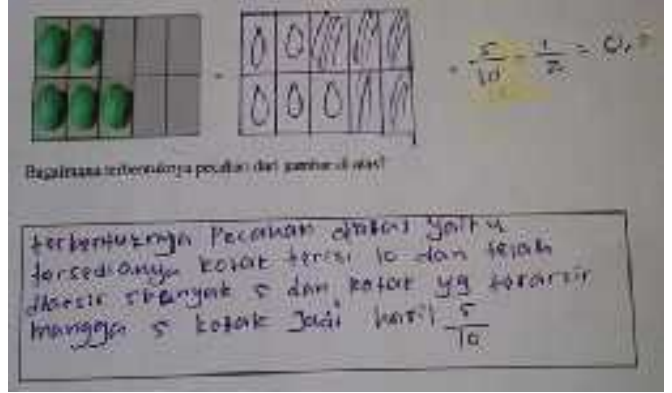

$\mathrm{b}$

Gambar 6. Hasil Pekerjaan S5

Gambar 6 merupakan hasil pekerjaan Subyek 5. Dalam merepresentasikan gambar, siswa tersebut mengarsir kotak yang tidak berisi benda konkrit, tetapi dia mampu merepresentasikan simbol aritmatika dengan mengikuti yang di gambar. Dalam menguraikan pemecahan masalah, S5 ini mampu memunculkan representasi verbal dalam menjelaskan representasi gambar. 


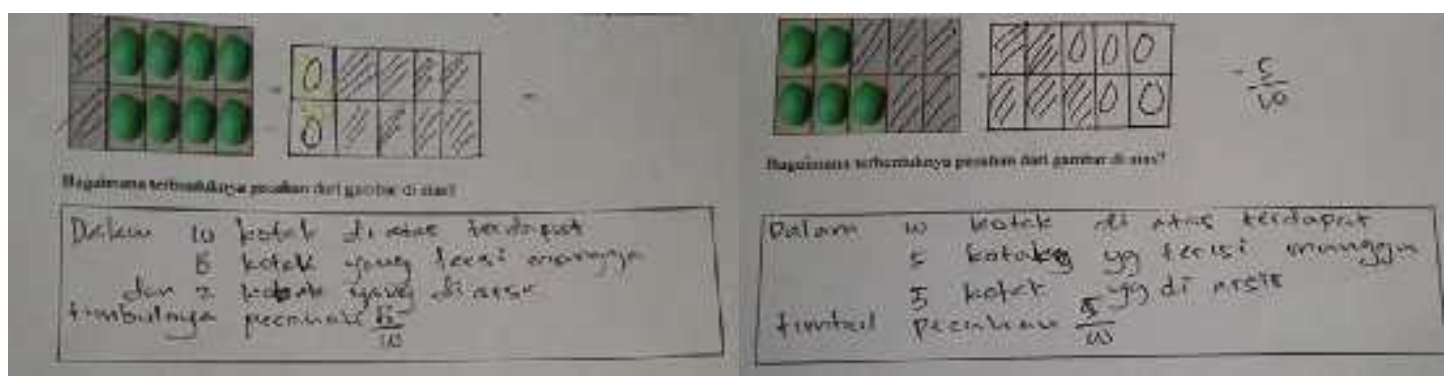

a

$\mathrm{b}$

Gambar 7. Hasil Pekerjaan S7

Gambar 7 merupakan hasil pekerjaan Subyek 7. Representasi yang dihasilkan oleh S7 ini sama dengan yang dihasilkan oleh S5 di atas, mampu memrepresentasikan penyelesaian masalah dalam bentuk gambar, simbol aritmatika, dan verbal. Representasi gambar yang dihasilkan oleh S7 mengikuti gambar konkrit, dan mampu merepresentasikan simbol aritmatika dengan lengkap.

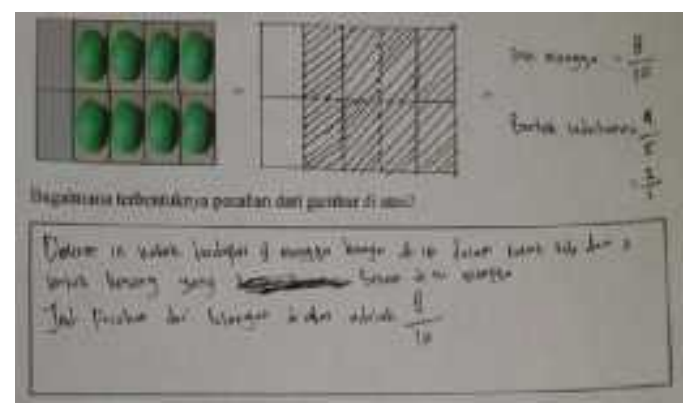

a

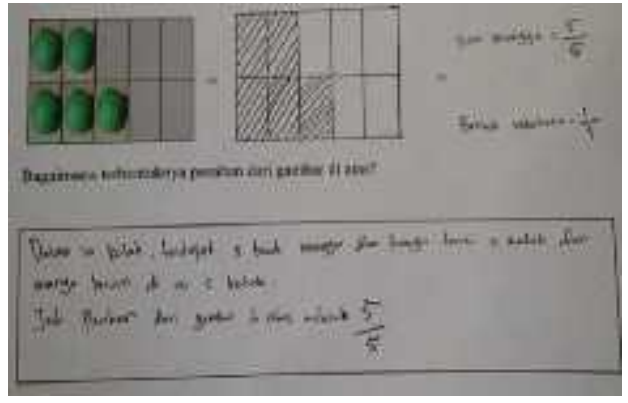

b

Gambar 8. Hasil Pekerjaan S8

Gambar 8 merupakan hasil pekerjaan Subyek 8. Dalam merepresentasikan gambar, S8 menunjukan pola yang tetap dan cenderung rapi. Kemudian representasi simbol aritmatika mengikuti gambar yang dihasilkan, tetapi pada proses penyederhanaan nya justru tidak mencerminkan nilai semula. Di gambar yang kedua, siswa tersebut berpikir bahwa gambar tersebut terpisah, sehingga berkesimpulan menjadi $\frac{\mathfrak{g}}{\mathrm{g}}$. Demikian juga representasi verbal yang dihasilkan, pemikirannya masih terpisah.

\section{PEMBAHASAN}

Representasi bagi siswa sangat diperlukan dalam menyelesaikan masalah matematika. Dari hasil penelitian di atas dapat uraikan bahwa beberapa jenis representasi dalam pemecahan masalah pecahan sudah ditunjukan oleh siswa. Beberapa jenis representasi tersebut diantaranya adalah representasi gambar, representasi simbol aritmatika, dan representasi 
verbal. Dari ketiga representasi yang muncul, setiap siswa menunjukan representasi yang berbeda dalam penyelesaian masalah pecahan. Representasi yang dihasilkan tersebut merupakan representasi secara eksternal yang berupa simbolisasi aljabar dan aritmatika, gambar/sketsa, dan verbal (Syarifuddin, 2018).

Dari hasil pekerjaan S2 dan S4, belum mampu merepsentasikan secara verbal bentuk pecahan yang mereka gambarkan. S2 lebih dominan menggunakan simbol aritmatika dalam memecahkan masalah pecahan, sedangkan S4, belum mampu sama sekali untuk menyelesaikan masalah pecahan. Kemudian dari hasil pekerjaan S5, S7, dan S8, menunjukan penggunaan representasi verbal dalam menyelesaikan masalah pecahan. Hanya saja dari ketiganya menunjukan representasi yang berbeda yaitu representasi gambar dan simbol aritmatika. Dalam penelitian Hackenberg (2015) bahwa representasi pecahan dapat menggunakan pendekatan kuantitatif, sehingga representasi dari bentuk tersebut dapat diwujudkan secara tertulis (gambar dan simbol) dan secara lisan (verbal).

\section{KESIMPULAN}

Dari hasil penelitian dan pembahasan, dapat disimpulkan: 1) masih ada siswa yang kesulitan dalam merepresentasikan verbal, gambar, dan simbol aritmatika nya tentang terbentuknya pecahan; 2) masih ada siswa yang penyelesaian masalah pecahan dengan mengguanakan representasi verbal tetapi tidak bisa merepresentasikan dengan simbol aritmatika dan gambar; 3) siswa masih kesulitan menyelesaikan masalah bentuk pecahan ke bentuk sederhana.

\section{REKOMENDASI}

Berdasarkan kesimpulan dari penelitian ini dapat memberikan rekomendasi untuk peneltian yang akan datang yaitu tentang representasi yang dihasilkan oleh siswa pada materi yang lain maupun pada tingkatan siswa di bawah atau di atas sekolah menengah pertama.

\section{REFERENSI}

Borko, H., \& Putnam, R. T. (1996). Learning to teach. In D. C. Berliner \& R. C. Calfe (Eds.), Handbook of Educational Psychology (pp. 673-708). New York: Simon \& Schuster MacMillan. 
Carlson, M. \& Bloom, I. (2005). The Cyclic Nature Of Problem Solving: An Emergent Multidimensional Problem-Solving Framework. Educational Studies In Mathematics, 58 (1): 45-75.

Hackenberg, A. J., \& Lee, M. Y. (2015). Relationships between students' fractional knowledge and equation writing. Journal for Research in Mathematics Education, 46(2), 196-243.

Hwang, W.-Y., Chen, N.-S., Dung, J.-J., \& Yang, Y.-L. (2007). Multiple Representation Skills and Creativity Effects on Mathematical Problem Solving using a Multimedia Whiteboard System. Educational Technology \& Society, Vol 10 No 2, pp. 191-212.

Jones, A.D. (2000) The fifth process standard: An argument to include representation in standar 2000. [on-line]. Available: http://www.math.umd.edu/ dac/650/jonespaper.html.

Jones, B.F., \& Knuth, R.A. (1991). What does research ay about mathematics? [on-line]. Available: http://www. ncrl.org/sdrs/areas/stw_esys/2math.html.

Lester, F. K. \& Kehle, P. 2003. From problem solving to modeling: The evolution of thinking about research on complex mathematical activity. In R. Lesh \& H. M. Doerr (Eds.), Beyond constructivism: Models and modeling perspectives on mathematics problem solving, learning, and teaching (501-517). Mahwah, NJ: Erlbaum.

NCTM . 2000. Principles and standards for school mathematics. Reston, VA: NCTM.

Sabirin, M. (2014). Representasi dalam Pembelajaran Matematika. Jurnal Pendidikan Matematika, 1(2).

Schoenfeld, A.H. 1983. The Wild, Wild, Wild, Wild, Wild World Of Problem Solving: A Review Of Sorts, For The Learning Of Mathematics 3, 40-47.

Spelke, E. S. (2000). Core knowledge. American psychologist, 55(11), 1233.

Sriraman, B. (2003). Mathematical Giftedness, Problem Solving, And The Ability to Formulate Generalizations. The Problem Solving Experiences of Four Gifted Students. The Journal of Secondary Gifted Education, 14 (3): 151-165.

Syarifuddin, S. (2018). Representasi Penalaran Kuantitatif Siswa dalam Pemecahan Masalah Matematika. Dalam Prosiding Seminar Nasional Lembaga Penelitian dan Pendidikan (LPP) Mandala (pp. 434-438). 